\title{
Carbonation of surface protected concrete
}

\author{
José B. Aguiar*, Cristela Júnior \\ Department of Civil Engineering, University of Minho, Campus of Azurém, Guimarães, Portugal
}

\section{H I G H L I G H T S}

- The carbonation of concretes with surface protection was evaluated.

- The concretes were protected with systems based in siloxane, acrylic and epoxy resins.

- The surface protected concretes presented lower carbonation diffusion coefficients than the non-protected concretes.

- The prescriptive methodology is not a guarantee to obtain the desired service lives of 50 or 100 years.

- The desired services lives were only obtained with the use of surface protection treatments.

\section{A R T I C L E I N F O}

\section{Article history:}

Received 15 May 2013

Received in revised form 1 August 2013

Accepted 29 August 2013

\section{Keywords:}

Carbonation

Corrosion

Epoxy

Acrylic

Siloxane

Service life

\begin{abstract}
A B S T R A C T
Concrete structures are exposed to carbonation that may cause rapid decay, shortening their service life and raising maintenance and repair costs. Carbonation lowers the alkalinity of the concrete depassivating the steel reinforcement. Two limit states can be identified with regard to service life. The first limit state ends when the steel is depassivated. The second limit state is based on cracking of the concrete cover due to oxides generated during corrosion. The service life includes a certain propagation period of corrosion during which the cross-sectional area of steel is progressively decreased, the bond between steel and concrete is reduced and the effective cross-sectional area of concrete is diminished due to spalling of the cover.

Surface treatment is commonly used to improve the resistance of concrete to carbonation. A barrier is formed retarding the carbonation reactions in the interior of the concrete. In this study surface protected concretes were compared with non-protected concretes. The used surface protected concretes presented generally lower carbonation diffusion coefficients than the non-protected concretes. The use of epoxy resin showed better protection than the use of acrylic and siloxane resins. The composition of the concretes is an important factor affecting the diffusion of carbonation. The influence of the water-cement ratio was very important. The carbonation diffusion coefficients increased with the water-cement ratio. The prescriptive methodology is not a guarantee to obtain the desired service lives of 50 or 100 years. The desired services lives were only obtained with the use of surface protection treatments.
\end{abstract}

(c) 2013 Elsevier Ltd. All rights reserved.

\section{Introduction}

According to Eurocode EN 1992-1-1 [1] a durable structure shall meet the requirements of serviceability, strength and stability throughout its intended working life, without significant loss of utility or excessive maintenance. There is often a need for supplementary measures to protect concrete in aggressive environment. Surface treatment is commonly used to improve the resistance of such concrete against the penetration of aggressive substances, both in new and existing structures [2]. Various generations of surface protection materials have been developed to counteract the

\footnotetext{
* Corresponding author. Fax: +351253510217.

E-mail address: aguiar@civil.uminho.pt (J.B. Aguiar).
}

aggressive actions of the environment against concrete. Between the most used we can find siloxane, acrylic and epoxy resins.

Natural concrete carbonation is a chemical reaction that involves the dissolution of atmospheric carbon dioxide in the pore water and the formation of a weak carbonic acid which dissociates and reacts with the calcium hydroxide resulting calcium carbonate and water [3]. The reactions are given in Eqs. (1) and (2), and a simplified graphic illustrating the reactions in Fig. 1.

$\mathrm{CO}_{2}+\mathrm{H}_{2} \mathrm{O} \rightarrow \mathrm{H}_{2} \mathrm{CO}_{3}$

$\mathrm{Ca}(\mathrm{OH})_{2}+\mathrm{H}_{2} \mathrm{CO}_{3} \rightarrow \mathrm{CaCO}_{3}+2 \mathrm{H}_{2} \mathrm{O}$

However, in addition to these reactions the carbon dioxide also reacts with $\mathrm{C}-\mathrm{S}-\mathrm{H}$ in concrete to form additional calcium carbonate [4]. Carbonation starts at the concrete surface including the surfaces of any cracks throughout the life of the concrete [5]. After, 


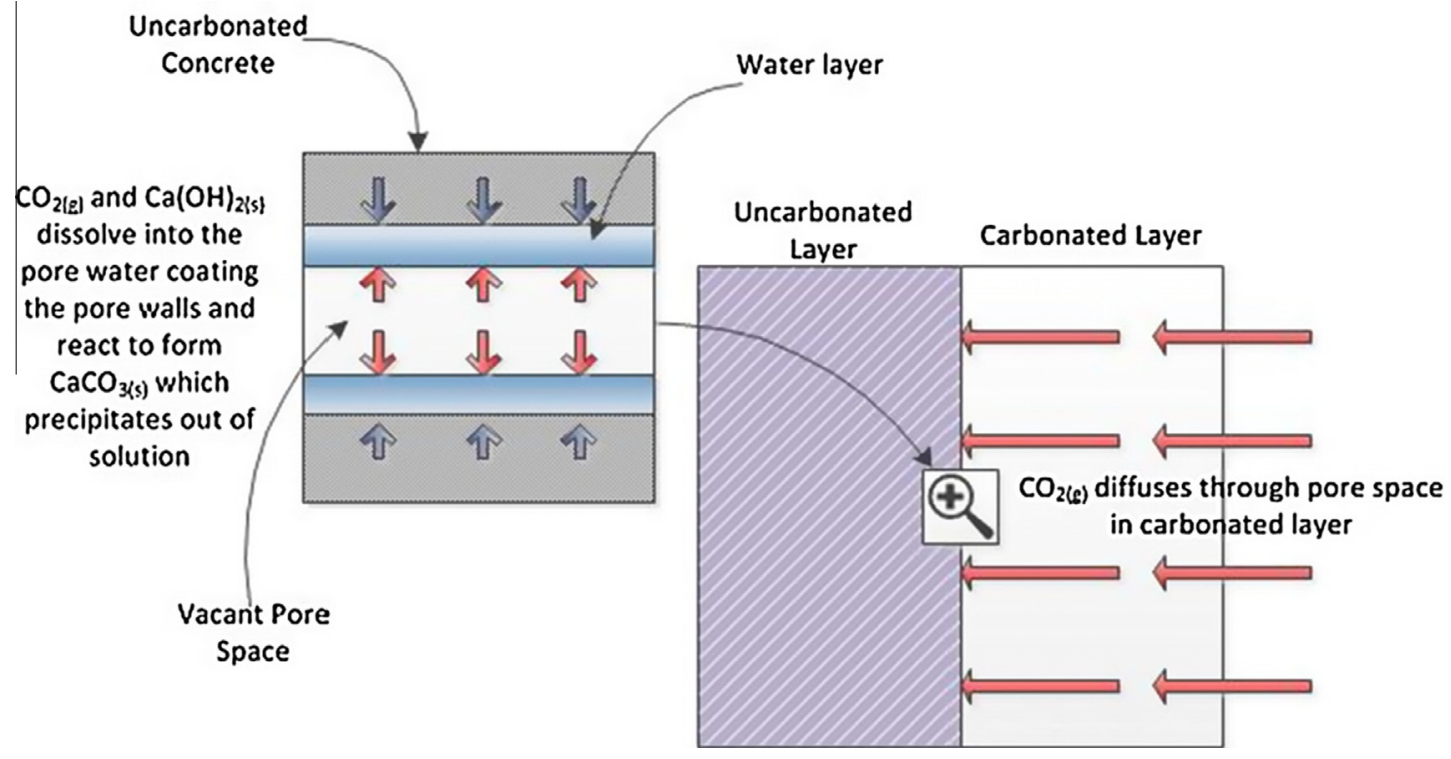

Fig. 1. Carbonation schematic [4].

carbonation penetrates inside of the concrete. This reaction lowers the alkalinity of the concrete depassivating the steel reinforcement [6].

Park [7] asserted that one-half of carbon dioxide in concrete reacts with calcium hydroxide while the other half reacts with $\mathrm{C}-\mathrm{S}-\mathrm{H}$. This assertion was further supported by Glasser and Matschei [8] who showed that the reaction would occur in sequence, with calcium hydroxide first being consumed and then $\mathrm{C}-\mathrm{S}-\mathrm{H}$ reacting thereby densifying the microstructure.

Based on reference documents $[9,10]$ the Portuguese standard NP EN 206-1 [11] for the design of concrete compositions includes two alternative specifications - prescriptive [12] and performancebased [13] - in view of environmental exposure.

The prescriptive methodology LNEC E464 [12] sets the limits of the concrete constituents (maximum $\mathrm{w} / \mathrm{c}$ ratio, minimum cement dosage and cement type), the minimum compressive strength and the concrete cover thickness for a design working life of 50 years (target period) under the environmental exposures classes in issue. Eurocode 2 [1] defines and describes environmental exposure classes in view of the aggressive agent. For carbonation induced corrosion four classes are defined and described: XC1, XC2, XC3 and XC4 (Table 1).

The performance-based specification makes no restriction concerning constituents and dosage. The criterion is related to the modeling lifetime result (service life) based on testing results of accelerated carbonation on concrete samples of the designed concrete composition [6].

Two limit states can be identified with regard to service life (Fig. 2). This ends when the steel is depassivated. The limit state is based on cracking of the concrete cover due to oxides generated during corrosion. The service life includes a certain propagation

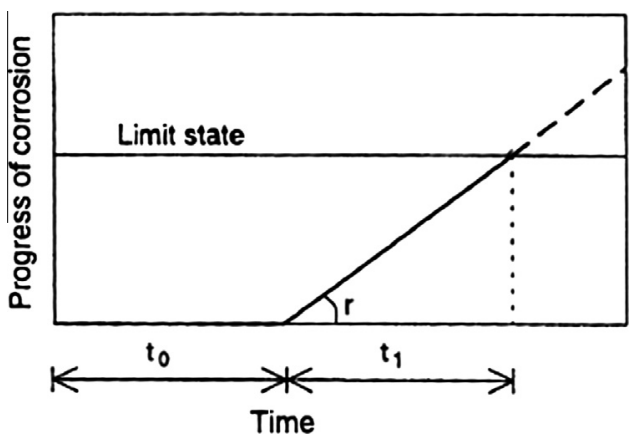

Fig. 2. Determination of service life with respect to corrosion of reinforcement [9].

period of corrosion during which the cross-sectional area of steel is progressively decreased, the bond between steel and concrete is reduced and the effective cross-sectional area of concrete is diminished due to spalling of the cover [9].

The initiation period concerning the penetration of carbon dioxide is based on the model of CEB [10] which the specification LNEC E465 [13] adopted considering the Portuguese environment. This model expresses the diffusivity of hardened concrete and it relates the concrete carbonation with time as follows:

$x=\sqrt{\frac{2 h}{R_{\mathrm{C} 65}}} \sqrt{k_{0} k_{1} k_{2}}\left(\frac{t_{0}}{t}\right)^{n}$

where due to carbonation, steel depassivation starts when a depth $x$ equals the concrete cover $c$ of the reinforcement steel. $R_{\mathrm{C} 65}\left(\left(\mathrm{~kg} / \mathrm{m}^{3}\right)\right.$

Table 1

Environmental exposure classes for carbonation induced corrosion [1].

\begin{tabular}{|c|c|c|}
\hline Exposure class & Description & Informative examples where exposure classes may occur \\
\hline $\mathrm{XC1}$ & Dry or permanently wet & $\begin{array}{l}\text { Concrete inside buildings with low air humidity } \\
\text { Concrete permanently submerged in water }\end{array}$ \\
\hline $\mathrm{XC2}$ & Wet, rarely dry & $\begin{array}{l}\text { Concrete surfaces subject to long-term water contact } \\
\text { Many foundations }\end{array}$ \\
\hline $\mathrm{XC3}$ & Moderate humidity & $\begin{array}{l}\text { Concrete inside buildings with moderate or high air humidity } \\
\text { External concrete sheltered from rain }\end{array}$ \\
\hline $\mathrm{XC4}$ & Cyclic wet and dry & Concrete surfaces subject to water contact, not within exposure class $\mathrm{XC2}$ \\
\hline
\end{tabular}


Table 2

Constant parameters $k_{1}$ and $n$ for carbonation exposure classes [1].

\begin{tabular}{lllll}
\hline Parameter & XC1 & XC2 & XC3 & XC4 \\
\hline$k_{1}$ & 1.00 & 0.20 & 0.77 & 0.41 \\
$n$ & 0 & 0.183 & 0.02 & 0.085
\end{tabular}

$\left(\mathrm{m}^{2} /\right.$ year $)$ ) defines the carbonation resistance obtained from the accelerated test with a relative humidity of $65 \%$ [14].

$R_{\mathrm{C} 65}=\frac{2 C_{\mathrm{accel}} t_{1}}{X_{1}^{2}}=\frac{2 C_{\mathrm{accel}}}{k^{2}}$

where $X_{1}$ is the carbonation depth (m), $t_{1}$ is the time (years), $C_{\text {accel }}$ is the carbon dioxide concentration $\left(90 \times 10^{-3} \mathrm{~kg} / \mathrm{m}^{3}\right), k$ is the carbonation coefficient $(\mathrm{m} / \sqrt{\text { year }})$.

$\Delta C=0.7 \times 10^{-3} \mathrm{~kg} / \mathrm{m}^{3}$ (difference of carbon dioxide concentration between the exterior and the carbonation front), $k_{0}=3$ is a constant value that accounts for the testing method and conditions $[13,14], k_{1}$ is the constant that accounts for the presence of relative humidity, $k_{2}$ is the constant that accounts for the curing influence: 1.0 for normalized cure and 0.25 for a 3 days period of curing, $t_{0}$ is the reference period $=1$ year and $n$ is the parameter that accounts for the wet/dry cycle influence in time [13]. Table 2 shows the values of parameters $k_{1}$ and $n$ for all exposure classes.

The end of the initiation period to the depassivation due to carbonation and hence from Eq. (3) $t$ becomes the initiation period $t_{i}$ expressed as:

$t_{i}=\left(\frac{R_{C 65} C^{2}}{1.4 \times 10^{-3} k_{0} k_{1} k_{2} t_{0}^{2 n}}\right)^{\frac{1}{1-2 n}}$

The performance-based specification [13] permits some flexibility in using water/binder ratios, dosage and types of cement different to those imposed by traditional prescriptive approach [12]. However the use of protection systems should be validated. This article presents results that include strength and carbonation of concretes protected and non-protected. Two concrete compositions were studied. One composition respects the prescriptive specification LNEC E464 [12]. The other composition does not respect this specification.

The surface protection materials for concrete can be classified into three groups: pore liner (makes the concrete water repellent), pore blocker (reacts with certain soluble concrete constituents and forms insoluble products) and coatings (form continuous film on concrete surface) [15]. This article study the carbonation of concretes protected with systems based in siloxane, acrylic and epoxy resins.

The starting product for most silicon-organic compounds is alkyl-trichloro-silane. By transformation of this silane with alcohol only, the corresponding alkyl-trialkoxy-silane is produced together with separation of hydrogen-chloride. The siloxane resins are obtained from the reaction of one silane with alcohol and water [16]. Acrylic resins are defined as a family of polymers resulting from the polymerization of derivatives of acrylic and methacrylic acids, such as butyl acrylate and methyl methalcrylate, respectively $[17,18]$.

Epoxy systems usually used as binders for coatings are twocomponent systems, one component containing the epoxy resin and the second the hardening agent. Most epoxy resins are synthesized by combining one molecule of bisphenol (derived from acetone and phenol) with two molecules of epichlorohydrin. This process forms the epoxy resin component, which contains both epoxide and hydroxyl functional groups. In polymerization, the resin molecules chemically react with a hardener to form the
Table 3

Chemical composition of the cement.

\begin{tabular}{lc}
\hline Chemical composition & CEM I 42.5R (\%) \\
\hline $\mathrm{SiO}_{2}$ & 19.64 \\
$\mathrm{Al}_{2} \mathrm{O}_{3}$ & 4.34 \\
$\mathrm{Fe}_{2} \mathrm{O}_{3}$ & 3.10 \\
$\mathrm{CaO}$ & 62.82 \\
$\mathrm{MgO}$ & 2.43 \\
$\mathrm{SO}_{3}$ & 3.33 \\
$\mathrm{Cl}^{-}$ & 0.02 \\
Loss on ignition & 3.2 \\
Insoluble residue & 0.90 \\
\hline
\end{tabular}

Table 4

Physical characteristics of the cement.

\begin{tabular}{ll}
\hline Physical characteristics & CEM I $42.5 \mathrm{R}$ \\
\hline Density $\left(\mathrm{kg} / \mathrm{m}^{3}\right)$ & 3110 \\
Blaine specific surface $\left(\mathrm{m}^{2} / \mathrm{kg}\right)$ & 3873 \\
Fineness $-45 \mu \mathrm{m}(\%)$ & 3.1 \\
Water demand $(\%)$ & 28.6 \\
\hline
\end{tabular}

Table 5

Composition of the concretes.

\begin{tabular}{lcc}
\hline Materials $\left(\mathrm{kg} / \mathrm{m}^{3}\right)$ & Concrete $0.6(\mathrm{C} 0.6)$ & Concrete $0.7(\mathrm{C} 0.7)$ \\
\hline Cement CEM I & 280 & 280 \\
Gravel 6-12 & 616 & 598 \\
Sand 0-4 & 1284 & 1227 \\
Water & 171 & 199 \\
\hline
\end{tabular}

polymer. The hardener commonly contains amine groups that react with the epoxide group $[17,18]$.

\section{Experimental program}

\subsection{Materials}

Portland cement (CEM I 42.5) was used. Table 3 shows the chemical composition of the cement. Table 4 shows some physical characteristics of the selected cement. Two crushed granite were used as aggregates. One with a density of $2630 \mathrm{~kg}$ $\mathrm{m}^{3}$, water absorption of $0.4 \%$, fineness modulus of 5.94 and a maximum size of $12.00 \mathrm{~mm}$. Another with a density of $2660 \mathrm{~kg} / \mathrm{m}^{3}$, water absorption of $0.2 \%$, fineness modulus of 3.95 and a maximum size of $4.00 \mathrm{~mm}$.

Two types of concretes were used. The composition of the concretes is presented in Table 5 . The two concretes had a cement content of $280 \mathrm{~kg} / \mathrm{m}^{3}$. The results of the slump test were $10 \mathrm{~mm}$ for the concrete with water-cement ratio of 0.6 (C0.6) and $110 \mathrm{~mm}$ for the concrete with water-cement ratio of 0.7 (C0.7). The average compressive strength, at 28 days, for the concrete $\mathrm{C} 0.6$ was $35.0 \mathrm{~N} / \mathrm{mm}^{2}$ and for the concrete $\mathrm{C} 0.7$ was $27.0 \mathrm{~N} / \mathrm{mm}^{2}$. The experimental campaign was designed in order to test unprotected and protected concrete specimens.

Surface protection products were selected to represent the following three generic types:

- Siloxane pore liner $(S)$.

- Acrylic resin coating (A).

- Epoxy resin coating (E).

The three types were selected between the more used products for concrete protection. This study started with each generic type represented by two products from different producers. The selection was made has presented in a previous paper [19]. Table 6 presents some properties of the selected products. All materials were applied by brush on the lateral surface of the cylinders after curing for 28 days, following the recommendations of the producers. The surface protection materials hardened, under laboratory conditions, for 7 days before following the tests.

\subsection{Carbonation test method}

The carbonation tests followed the Portuguese specification LNEC E391 [14]. Testing samples were cylindrical with $100 \mathrm{~mm}$ diameter and $200 \mathrm{~mm}$ height. Before entering the carbonation chamber, samples were cured in water saturated environment until 14 days and after in the air at $50 \% \mathrm{RH}$ and $20^{\circ} \mathrm{C}$ till the age of 28 days. The following accelerated carbonation environment was $65 \% \mathrm{RH}, 20^{\circ} \mathrm{C}$ and $5 \%$ of 
Table 6

Properties of the selected products.

\begin{tabular}{llll}
\hline Property & Siloxane resin in solvent & Acrylic resin aqueous based & Two component epoxy resin \\
\hline Consistency & Liquid & Dense liquid & Dense liquid \\
Coverage rate $\left(\mathrm{m}^{2} / \mathrm{dm}^{3}\right)$ & 2.8 & 3.5 & 4.0 \\
Density at $20^{\circ} \mathrm{C}\left(\mathrm{kg} / \mathrm{dm}^{3}\right)$ & 0.83 & 1.40 & 1.30 \\
Brookfield viscosity at $20^{\circ} \mathrm{C}(\mathrm{mPa} \mathrm{s})$ & 11 & 6000 & 1500 \\
Surface drying time $(\mathrm{min})$ & 60 & 40 & 300 \\
Interval between coats (h) & 2 & 24 & 24 \\
\hline
\end{tabular}

$\mathrm{CO}_{2}$ air content. For each composition one sample was removed and had its carbonation depth analyzed at three different dates, 7, 14 and 28 days, after enter the carbonation chamber. Each sample was sliced in two halves and sprayed with phenolphthalein. The result of carbonation depth corresponds to the thickness with no change of color, while the remaining area (with change of color) indicates $\mathrm{pH}>9$. This method slightly underestimates the carbonation depth [20] since the reaction occurs for a $\mathrm{pH}<10-11$. This associated error was simply assumed and the procedure and corresponding analysis were nevertheless carried out [6].

(a)

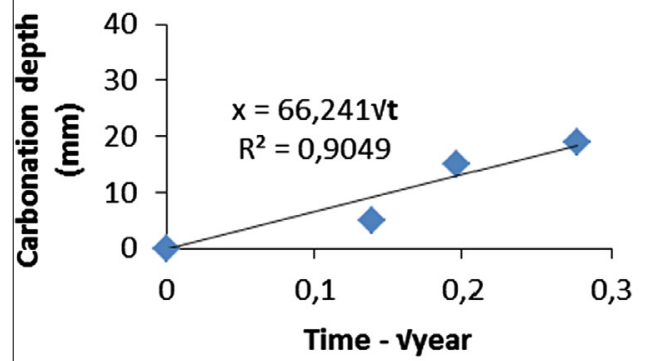

(c)

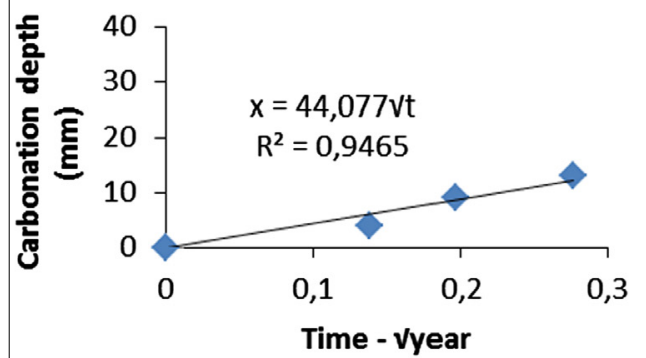

(e)

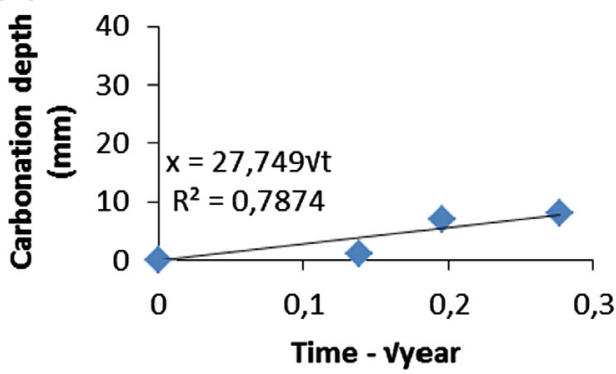

(g)

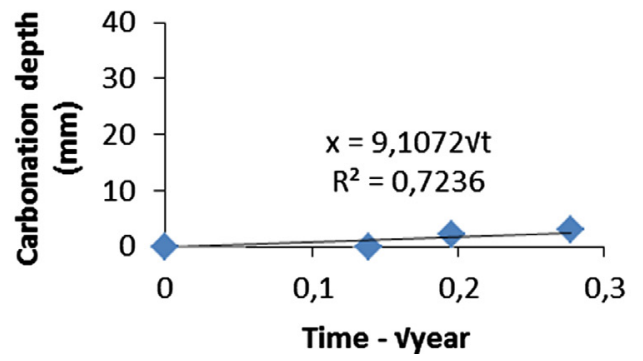

\section{Results and discussion}

\subsection{Carbonation tests}

Fig. 3 presents the accelerated carbonation results of each concrete unprotected and protected. Although with some variation, it

(b)

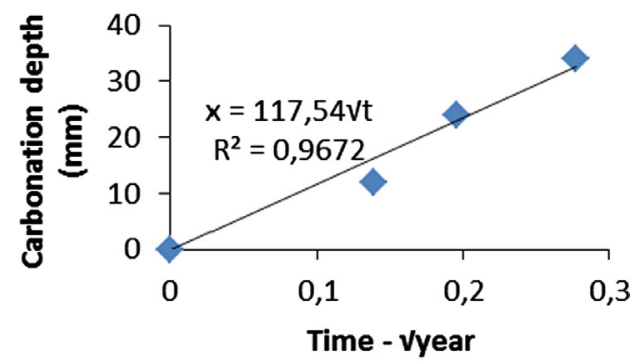

(d)

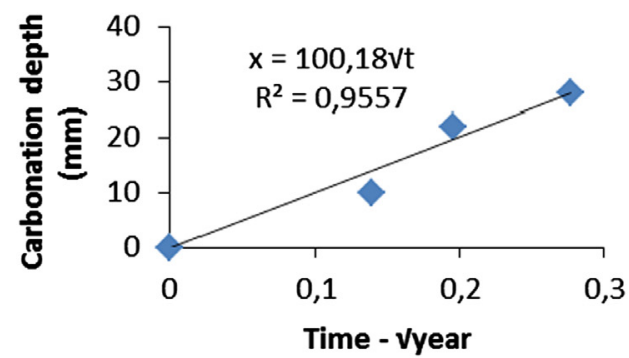

(f)

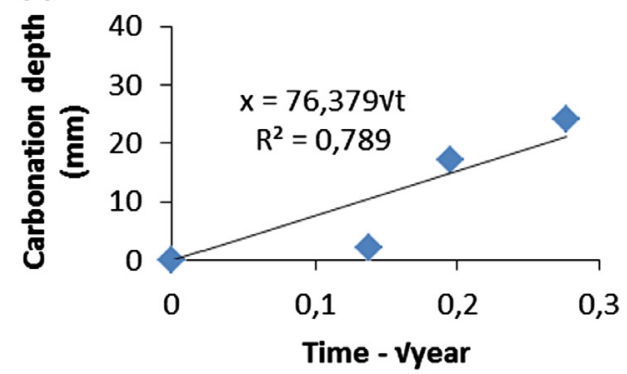

(h)

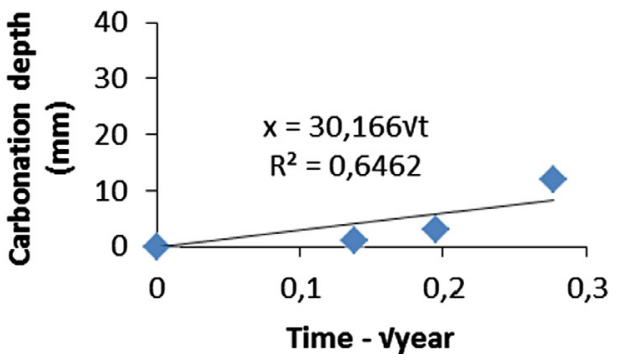

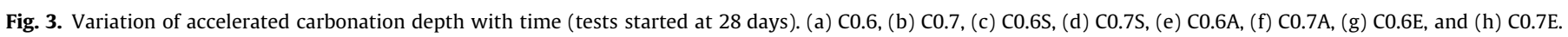


Table 7

Results of carbonation diffusion $k$ and carbonation resistance $R_{C 65}$.

\begin{tabular}{llcc}
\hline Concrete & Type of protection & $K(\mathrm{~mm} / \sqrt{\text { year }})$ & $R_{\text {C65 }}\left(\left(\mathrm{kg} / \mathrm{m}^{3}\right) /\left(\mathrm{m}^{2} /\right.\right.$ year $\left.)\right)$ \\
\hline C0.6 & Unprotected & 66 & 41 \\
C0.7 & Unprotected & 118 & 13 \\
C0.6S & Siloxane & 44 & 93 \\
C0.7S & Siloxane & 100 & 18 \\
C0.6A & Acrylic & 28 & 230 \\
C0.7A & Acrylic & 76 & 31 \\
C0.6E & Epoxy & 9 & 2222 \\
C0.7E & Epoxy & 30 & 200 \\
\hline
\end{tabular}

is considered that carbonation depth grows with the square root of time:

$X=k \sqrt{t}$

This way it is possible to obtain the carbonation coefficient $k$ represented by the slope of each regression (Fig. 3 and Table 7). The correlation coefficients obtained are above $90 \%$ for the unprotected concretes and for concretes protected with the siloxane re$\sin$. For the concretes protected with acrylic and epoxy resin the correlation coefficients are situated always under $80 \%$. This indicated that to take into account the presence of these resins, a regression different from linear may be consider to better representing the carbonation diffusion.

The carbonation diffusion coefficient increases with the watercement ratio. Considering the tested unprotected concretes the carbonation diffusion increases about $79 \%$ comparing the concretes C0.6 with C0.7. Thomas et al. [21] also determined the variation of carbonation diffusion coefficient with the water-cement ratio. However between 0.6 and 0.7 they found an increase of about $40 \%$. This increase of carbonation diffusion is due to the increase of the porosity with the water-cement ratio.

The protected concretes present usually lower carbonation diffusion coefficients than the unprotected concrete. However, the unprotected concrete C0.6 presents lower carbonation diffusion than the protected concretes C0.7S and C0.7A. This shows the importance of a low water-cement ratio in order to have low carbonation diffusion coefficient.

The siloxane resin reveals lower protection compared with the other protection systems. This is due to the nature of the siloxane resin that acts as pore liner, making the concrete water repellent. On the contrary the acrylic and epoxy resins act as coatings, forming continuous film on concrete surfaces. Epoxy resin presents better protection than acrylic resin confirming the results of Park [7]. The carbonation diffusion coefficient decreased about 65\% comparing concretes protected with acrylic resin (C0.6A and C0.7A) with concretes protected with epoxy resin (C0.6E and C0.7E)

\subsection{Service life analysis}

Marques et al. [6] present two methods for the modeling of the initiation period: the partial safety factor method (semi-probabilistic) and the probabilistic method [13]. The results obtained with these two methods were similar [6]. So, in this study only the first method will be used.

The estimation of the service life period using the partial safety factor method has been carried out considering the exposure class XC4 for the target periods $t_{g}$ of 50 and 100 years with a cover $c_{\text {min,dur }}$ of respectively 40 and $50 \mathrm{~mm}$. The analysis was based on an established assumption $[13,22]$ that the performance limit is expressed as reliability index $\beta \geqslant 1.5$ or probability of failure $P_{f} \leqslant 7 \%$.

The propagation period corresponds to the beginning of corrosion of steel reinforcement within the concrete. This causes the loss of section of steel bars which results into loss of strength of the steel reinforcement itself. Additionally, there is an increase of volume of the corrosion product around steel bars which leads to internal stresses against the surrounding concrete and consequent loss of bond between concrete and steel [23].

The specification LNEC E465 [13] specifies different minimum propagation periods $t_{p}$ for each exposure class and different minimum required target periods $t_{g}$ (Table 8 ). The design service life, $t_{L}$, is calculated as:

$t_{L}=\frac{t_{i}}{\gamma}+t_{p}$

where $t_{i}$ is the initiation period obtained from Eq. (5), $\gamma$ is the safety factor associated to the reliability class (Table 9 ), and $t_{p}$ is the propagation period given in Table 8 .

Table 10 shows the results of design service life of RC structures included in exposure class XC4 using a safety factor of $\gamma=2.3$ (Eq. (7) and Table 9). About the unprotected concretes, the required service life of 50 years is only reached with the concrete C0.6 and for dry region. The required service life of 100 years is not reached with both concretes C0.6 and C0.7. This is an unexpected result because at least the concrete $\mathrm{C} 0.6$ should reach the required service lives because its composition respect all the exigencies of the specification LNEC E464 [12]. Marques et al. [6] used concrete also with CEM I but with lower water-cement ratio (0.55) and with higher cement content ( 330 and $360 \mathrm{~kg} / \mathrm{m}^{3}$ ). The design service life found by Marques et al. [6] was about 180 years and 350 years for required service lives of 50 years and 100 years, respectively.

The design service life increases with the surface protection. The higher service life was obtained with the epoxy resin protection (C0.6E and C0.7E). About protected concretes the lower service life was obtained with siloxane resin ( $\mathrm{C} 0.6 \mathrm{~S}$ and $\mathrm{C0.7S}$ ). This is due to the type of barrier formed by the different protection systems. The siloxane resin acts as pore liner and both acrylic and epoxy resins act as continuous coating. The acrylic and epoxy resins also present high viscosity.

The concrete with water-cement ratio of 0.6 reached the desired service lives with all the protection systems tested $(\mathrm{C} 0.6 \mathrm{~S}$, C0.6A and C0.6E). About the other concrete, with water-cement ratio of 0.7 , the desired service life was only obtained with the epoxy resin protection (C0.7E). Design values of service life higher than 200 years are difficult to be accepted as realistic.

The used method did not take into account the degradation of the protection systems. Under real circumstances, organic coatings degrade naturally as a result of heat, moisture, ultraviolet radiation, etc. [7]. In order to guarantee the high values obtained with

Table 8

Minimum propagation periods from corrosion onset until cracking [13].

\begin{tabular}{lll}
\hline Exposure class & $\begin{array}{l}t_{\mathrm{g}}=50 \text { years } \\
t_{p} \text { Estimated (years) }\end{array}$ & $\begin{array}{l}t_{\mathrm{g}}=100 \text { years } \\
t_{p} \text { Estimated (years) }\end{array}$ \\
\hline XC1 & $>100$ & $>100$ \\
XC2 & 10 & 20 \\
XC3 & 45 & 90 \\
XC4 & $15-$ dry region & $20-$ dry region \\
& $5-$ wet region & $10-$ wet region \\
\hline
\end{tabular}

Table 9

Safety factor $\gamma$ values for each reliability class [13].

\begin{tabular}{ll}
\hline Reliability class & Safety factor value \\
\hline RC1 & 2.0 \\
RC2 & 2.3 \\
RC3 & 2.8 \\
\hline
\end{tabular}


Table 10

Design service life: partial safety factor method - class XC4.

\begin{tabular}{|c|c|c|c|c|}
\hline Concrete & $R_{C 65}\left(\left(\mathrm{~kg} / \mathrm{m}^{3}\right) /\left(\mathrm{m}^{2} /\right.\right.$ year $\left.)\right)$ & $t_{g}=50$ years $c_{\text {min,dur }}=40 \mathrm{~mm} t_{L}$ (years) & $t_{g}=100$ years $c_{\text {min,dur }}=50 \mathrm{~mm} t_{L}$ (years) & Region \\
\hline \multirow[t]{2}{*}{ C0.6 } & 41 & 40 & 70 & Humid \\
\hline & & 50 & 80 & Dry \\
\hline \multirow[t]{2}{*}{$\mathrm{C} 0.7$} & 13 & 14 & 25 & Humid \\
\hline & & 24 & 35 & Dry \\
\hline \multirow[t]{2}{*}{ C0.6S } & 93 & 99 & 170 & Humid \\
\hline & & 109 & 180 & Dry \\
\hline \multirow[t]{2}{*}{$\mathrm{C} 0.7 \mathrm{~S}$} & 18 & 18 & 32 & Humid \\
\hline & & 28 & 42 & Dry \\
\hline \multirow[t]{2}{*}{ C0.6A } & 230 & 284 & 488 & Humid \\
\hline & & 294 & 498 & Dry \\
\hline \multirow[t]{2}{*}{ C0.7A } & 31 & 30 & 53 & Humid \\
\hline & & 40 & 63 & Dry \\
\hline \multirow[t]{2}{*}{$\mathrm{C} 0.6 \mathrm{E}$} & 2222 & $>500$ & $>500$ & Humid \\
\hline & & $>500$ & $>500$ & Dry \\
\hline \multirow[t]{2}{*}{ C0.7E } & 200 & 241 & 414 & Humid \\
\hline & & 251 & 424 & Dry \\
\hline
\end{tabular}

the protection resins it will be important their reapplication after periods of about $10-15$ years.

\section{Conclusion}

The used surface protected concretes presented generally lower carbonation diffusion coefficients than the non-protected concretes. This is due to the barrier effect introduced by the use of such surface protections. The use of epoxy resin showed better protection than the use of acrylic and siloxane resins. The composition of the concretes is an important factor affecting the diffusion of carbonation. The influence of the water-cement ratio was very important. The carbonation diffusion coefficients increased with the water-cement ratio. This is due to the increase of the porosity of the concrete. The prescriptive methodology is not a guarantee to obtain the desired service lives of 50 or 100 years. The desired services lives were only obtained with the use of surface protection treatments.

\section{References}

[1] EN 1992-1-1. Eurocode 2: Design of concrete structures. Part 1-1: general rules and rules for buildings. European committee for standardization. Brussels; 2004.

[2] Dai J-G, Akira Y, Wittmann FH, Yokota H, Zhang P. Water repellent surface impregnation for extension of service life of reinforced concrete structures in marine environments: the role of cracks. Cement Concrete Comp 2010;32:101-9.

[3] Richardson MG. Carbonation of reinforced concrete: its causes and management. Dublin: Citis; 1988.

[4] Talukdar S, Banthia N, Grace JR. Carbonation in concrete infrastructure in the context of global climate change - part 1: experimental results and model development. Cement Concrete Comp 2012;34:924-30.

[5] Khan MI, Lynsdale CJ. Strength, permeability, and carbonation of highperformance concrete. Cement Concrete Res 2002;32:123-31.

[6] Marques PF, Chastre C, Nunes A. Carbonation service life modeling of RC structures for concrete with portland and blended cements. Cement Concrete Comp 2013;37:171-84.
[7] Park DC. Carbonation of concrete in relation to $\mathrm{CO}_{2}$ permeability and degradation of coatings. Constr Build Mater 2008;22:2260-8.

[8] Glasser FP, Matschei T. Interactions between portland cement and carbon dioxide. In: Proceedings of the12th ICCC. Montreal, Canada; 2007.

[9] Sarja A, Vesikari E. Durability design of concrete structures: report of RILEM technical committee 130-CSL. London: E \& FN Spon; 1996.

[10] CEB Bulletin d'information No. 238. New approach to durability design - an example for carbonation induced corrosion; 1997.

[11] NP EN 206-1. Concrete - part 1: specification, performance, production and conformity. IPQ, Lisbon; 2005.

[12] LNEC E464. Concrete. Prescriptive methodology for a design working life of 50 and 100 years. LNEC, Lisbon; 2007.

[13] LNEC E465. Concrete. Methodology for estimating the concrete performance properties allowing to comply with the design working life of the reinforced or pre-stressed concrete structures under the environmental exposures XC and XS. LNEC, Lisbon; 2007.

[14] LNEC E391. Concrete. Determination of the carbonation resistance. LNEC, Lisbon; 1993.

[15] Medeiros MHF, Helene P. Surface treatment of reinforced concrete in marine environment: influence on chloride diffusion coefficient and capillary water absorption. Constr Build Mater 2009;23:1476-84.

[16] Schueremans L, Van Gemert D. Service life prediction model for reinforced concrete constructions treated with water-repellent compounds. In: Proceedings conchem conference and exhibition. Düsseldorf, Germany: 1997. p. $2-4$.

[17] ACI 548.5R-98. Guide for polymer concrete overlays. American Concrete Institute. Farmington Hills, MI, USA: ACI; 1998.

[18] ACI 548.3R-03. Polymer-modified concrete. American Concrete Institute. Farmington Hills, MI, USA: ACI; 2003.

[19] Aguiar J, Moreira P, Lukowski P, Czarnecki L, Camões A, Van Gemert D. Ranking procedure for polymeric coatings and hydrophobic agents for concrete protection. Restor Build Monum 2007;13:251-64.

[20] Lo Y, Lee HM. Curing effects on carbonation of concrete using a phenolphthalein indicator and fourier-transform infrared spectroscopy. Build Environ 2002;37:507-14.

[21] Thomas C, Setién J, Polanco JA, Alaejos P, Sánchez de Juan M. Durability of recycled aggregate concrete. Constr Build Mater 2013;40:1054-65.

[22] EN 1990. Eurocode 0: Bases of structural design. European committee for standardization, Brussels; 2002.

[23] Bentur A, Berke N, Diamond S. Steel corrosion in concrete: fundamentals and civil engineering practice. London: E\&FN Spon Press; 1998. 